\title{
Microbiological Pollution Indication as Tracer for the Pollution of Well Water: The Example of the District of Abomey-Calavi (Benin)
}

\author{
Parfait Sagnon Hounsinou1 ${ }^{*}$, Daouda Mama1, Micheline Agassounon Djikpo Tchibozo², \\ Moussa Boukari' ${ }^{1}$, Dominique Sohounhloue ${ }^{3}$ \\ ${ }^{1}$ Laboratoire d'Hydrologie Appliquée, Département de Chimie, Université d'Abomey-Calavi, Cotonou, Bénin \\ ${ }^{2}$ Laboratoire de Génétique et des Biotechnologies, Faculté des Sciences et Techniques (FAST), Université \\ d'Abomey-Calavi (UAC), Cotonou, Bénin \\ ${ }^{3}$ Laboratoire d'Etude et de Recherche en Chimie Appliquée, Département de Chimie, Université \\ d'Abomey-Calavi (UAC), Cotonou, Bénin \\ Email: "doctorantparfait@yahoo.fr
}

Received 14 January 2015; accepted 2 April 2015; published 3 April 2015

Copyright (C) 2015 by authors and Scientific Research Publishing Inc.

This work is licensed under the Creative Commons Attribution International License (CC BY).

http://creativecommons.org/licenses/by/4.0/

(c) (i) Open Access

\begin{abstract}
Water is indispensable at life. Resources in waters of the township of Abomey-Calavi are of national importance. The township of Abomey-Calavi is very close to the biggest plan of water Beninese lagoon: The Nokoué lake. Besides, not only the waters of the ground water are consumed by the majority of the population from the traditional well, but also, the underground waters of the terminal continnental of the township of Abomey-Calavi are exploited intensely by the Society Nationnale of the Waters of Benin (SONEB) to nourish in drinking water in the townships of AbomeyCalavi, of Cotonou the biggest city of the country and Sèmè. The microbiological parameter followup (total coliforms, coliforms thermotolerants and enterrococcis) to the level of many traditional well and deep boring and some different points of Nokoué lake were the object of a treatment of data by the establishment of card of fecal contamination of waters natural of the region, that informs us on the quality of waters by the slant of a microbiological quality indication that calculates itself according to the method of Bovesse and Depelchin (1980). The survey of the microbiological contamination indication, succeeds to the establishment of seasonal cards of quality of waters.
\end{abstract}

\section{Keywords}

Resources in Water, Microbiological Contamination, Total Coliforms, Coliforms Thermotolerants,

${ }^{*}$ Corresponding author.

How to cite this paper: Hounsinou, P.S., et al. (2015) Microbiological Pollution Indication as Tracer for the Pollution of Well Water: The Example of the District of Abomey-Calavi (Benin). Journal of Environmental Protection, 6, 290-298.

http://dx.doi.org/10.4236/jep.2015.64029 


\section{Enterrococcis}

\section{Introduction}

The bad microbiological quality of water can be misled by activities anthropiques or by natural phenomena [1]. In particular, the fecal contamination plays an important role in the microbiological deterioration of the underground waters and the waters of surface. Indeed, a gram of excretion includes a million to one billion of coliforms thermotolerants and one hundred, one thousand to 100 millions of intestinal enterococcis [2]. The tightness of the latrines and the septics is badly assured; there is percolation of the liquids in the surrounding soil, in the waters of surface and the underground waters. In the present survey, one intends to study the bacteriological quality of the waters of well, of the waters of boring and the waters of the Nokoué lake, because these last are currently in a serious state and constitute this fact a serious danger for the public health and they are a source of permanent contamination of the environment. In the survey region, during the season of rains, several people developed waterborne diseases and the cholera provoked some deaths.

\section{Materials and Methods}

\subsection{Presentation of the Survey Zone}

The township of Abomey-Calavi, situated in the South part of Republic of Benin and the Department of the Atlantic, is limited at the North by the township of Zè, to the South by the Atlantic Ocean, to the East by the townships of Sô-Ava and Cotonou and to the west by the townships of Tori-Bossito and Ouidah. It is the vast township of the department of the Atlantic of which it occupies more than $20 \%$ of the surface. It spreads on a surface of $536 \mathrm{~km}^{2}$ representative $0.48 \%$ the national surface of the common Benin. The township of AbomeyCalavi is very close to the biggest plan of water Beninese lagoon: The Nokoué lake. Indeed, Long of $20 \mathrm{~km}$ (East-west) and large of $11 \mathrm{~km}$ (North-South), the Nokoué lake has a surface of law water of about $160 \mathrm{~km}^{2}$ and represent the largest plan of water Beninese and most important lagoon of the point of view of its planning because of its proximity with the city of Cotonou [3]. The Nokoué lake influences the underground water pollution considerably close to him [4]. The township of Abomey-Calavi counts seventy (70) villages and districts of cities distributed on nine (09) precincts that are: Calavi-Centre, Godomey, Akassato, Zinvié, Ouèdo, Togba, Hêvié, Kpanroun and Glo-Djigbé [5]-[7] (Figure 1).

\subsection{Material}

Twenty five points of withdrawal of which twenty sites of sampling of water of well traditional, a site of sampling of deep boring water and four sites of sampling of surface water of the Nokoué lake are chosen (Figure 2). Our survey was based on four measures achieved during the big and the small season of rains and the big and the small dry season of the year 2013. During this study, the total coliforms, the coliforms thermotolerants and the intestinal enterrococcis have been measured by the method of incorporation on agar.

\subsection{Methods}

The method of treatment of data is based on the Microbiological Quality indication (IQM). The IQM depends on the concentrations in water of the total coliforms, the coliforms thermotolerants and the intestinal enterrococcis. One definite 5 classes of concentrations for each of these parameters (Table 1). The IQM is the average of the numbers of the classes of every parameter. The values of the IQM permit to distribute the microbiological pollutions of waters in 5 classes (Table 2) of quality correspondent to colors standards (Figure 3) [8].

\section{Result and Interpretation}

We present here the results as graphs in which the green followed it of analysis following the different points of withdrawal permitted to calculate the indications of microbiological quality of the natural waters of the township 


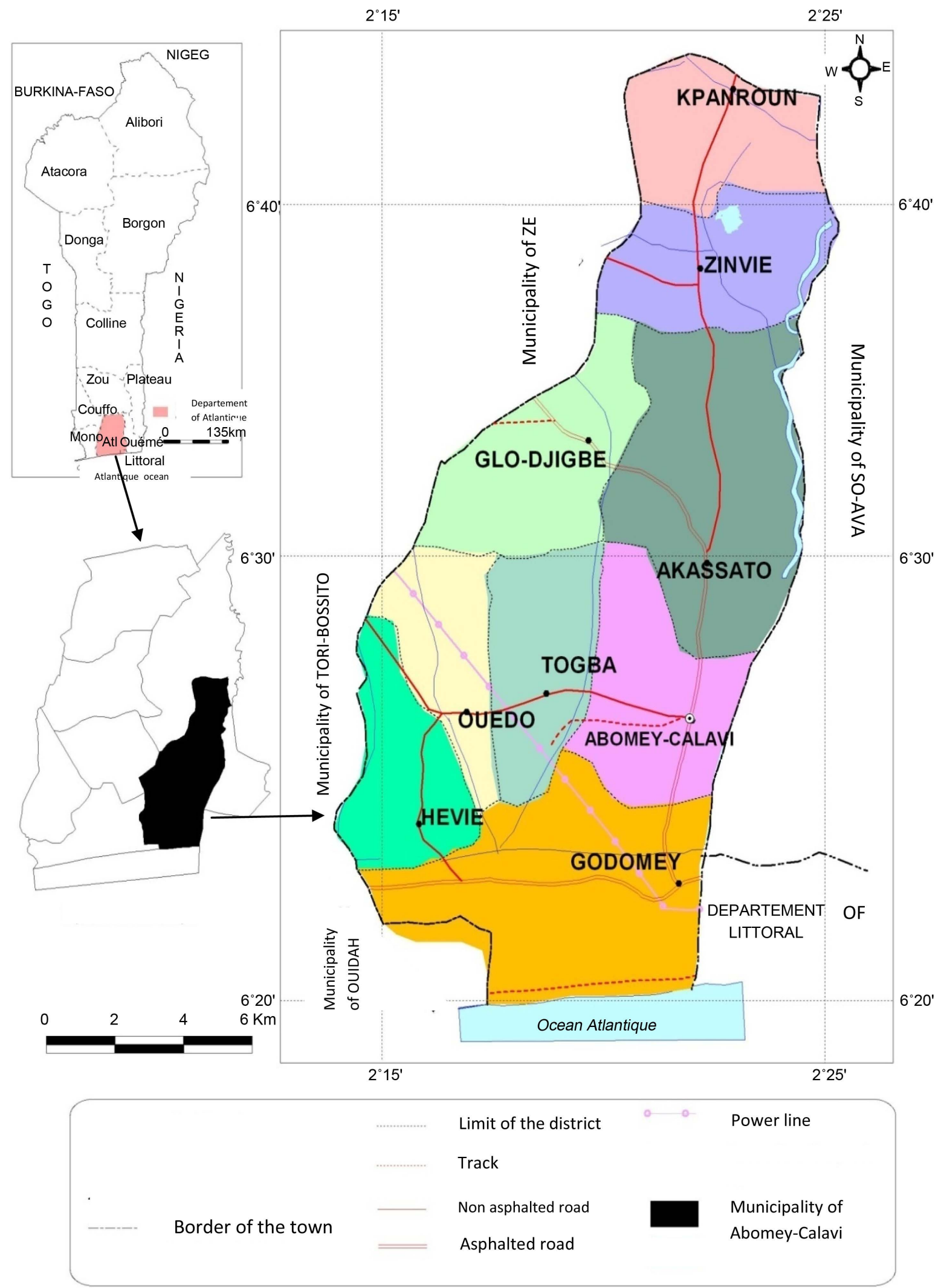

Figure 1. Location of the municipality of Abomey-Calavi. 


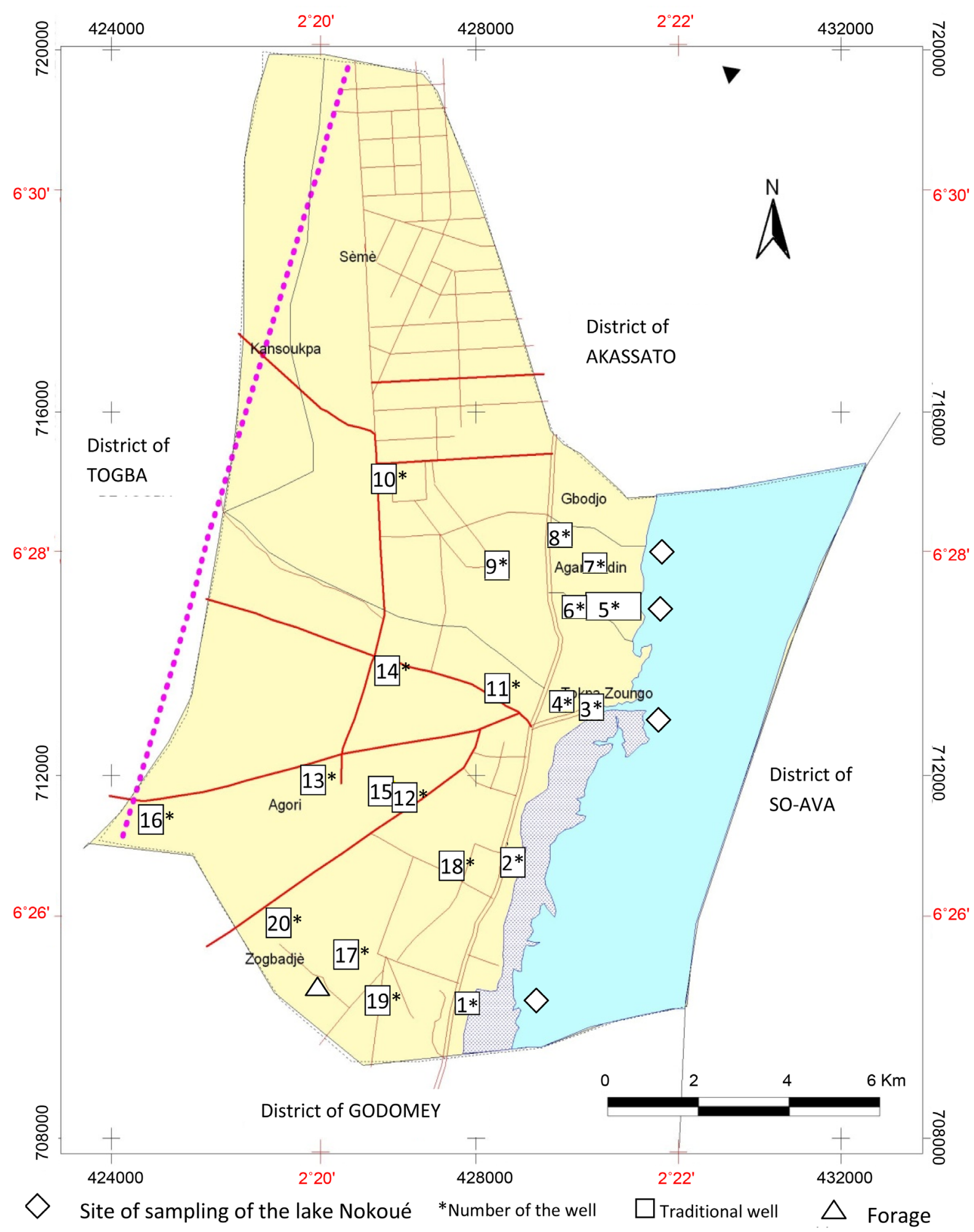

Figure 2. Well water sampling sites.

of Abomey-Calavi. We calculated the values of the microbiological quality indication (IQM) of the waters of traditional wells, the deeps borings and the Nokoué lake in the dry season and the rain season (Table 3).

The interpretation of the seasonal cards of indication of microbiological quality of the natural waters (The 


\section{Hopeless pollution in blue \\ Weak pollution in green \\ Strong pollution in orange \\ Very strong pollution in red.}

Figure 3. Color according to the classes of quality.

Table 1. Classes of quality corresponding to every parameters.

\begin{tabular}{cccc}
\hline & Total Coliforms $/ \mathrm{mL}$ & Coliforms thermotolerants $/ \mathrm{mL}$ & Intestinal enterococccis $/ \mathrm{mL}$ \\
\hline Class 5 & $<2000$ & $<100$ & $<5$ \\
Class 4 & $2000-9000$ & $100-500$ & $5-10$ \\
Class 3 & $9000-45,000$ & $500-2500$ & $10-50$ \\
Class 2 & $45,000-360,000$ & $2500-20,000$ & $50-500$ \\
Class 1 & $>360,000$ & $>20,000$ & $>500$ \\
\hline
\end{tabular}

Table 2. Level of microbiological pollution of waters according to the Microbiological Contamination indication (IQM).

\begin{tabular}{ccc}
\hline IQM & Level of microbiological pollution \\
\hline $4.3-5.0$ & Very weak (hopeless) \\
$3.5-4.2$ & Weak \\
$2.7-3.4$ & Moderate \\
$1.9-2.6$ & Strong \\
$1.0-1.8$ & Very strong \\
\hline
\end{tabular}

waters of the Nokoué lake, traditional well and boring) indicates the degree of change of the waters of the survey region. One notes that waters pass a good quality with strong indications $(4<\mathrm{IQM}<5)$ to a mediocre quality $(1<$ IQM $<2)$. In the region of survey, when one passes from the dry season at the season of rains, one notes in general that the microbiological underground water quality deteriorates whereas the one of the waters of the Nokoué lake improves (Figure 4 and Figure 5).

During the season of rains has a dilution of the waters of the Nokoué lake that has a better microbiological quality then that in dry season.

The septic pits and the latrines of the survey zone are not insulated. During the seasons of rains, the waters of infiltrations encourage the underground water pollution (waters of well and deep boring) by the septic pits and the latrines. The quality of the underground waters of the survey region deteriorates more than in seasons of rains that in dry season.

\section{Conclusion}

In conclusion, it is evident from the present survey that the variation of the bacteriological quality of the natural waters is bound to the rain water. Through these cards we can say that the seasonal variation is not very clear in the whole different sampling sites. The results of the analysis of waters permit to conclude that waters of the Nokoué lake have a better microbiological quality in season of the rains because they are dilute by the waters of rains while the microbiological underground water quality deteriorates in season of rains because the waters of 
P. S. Hounsinou et al.

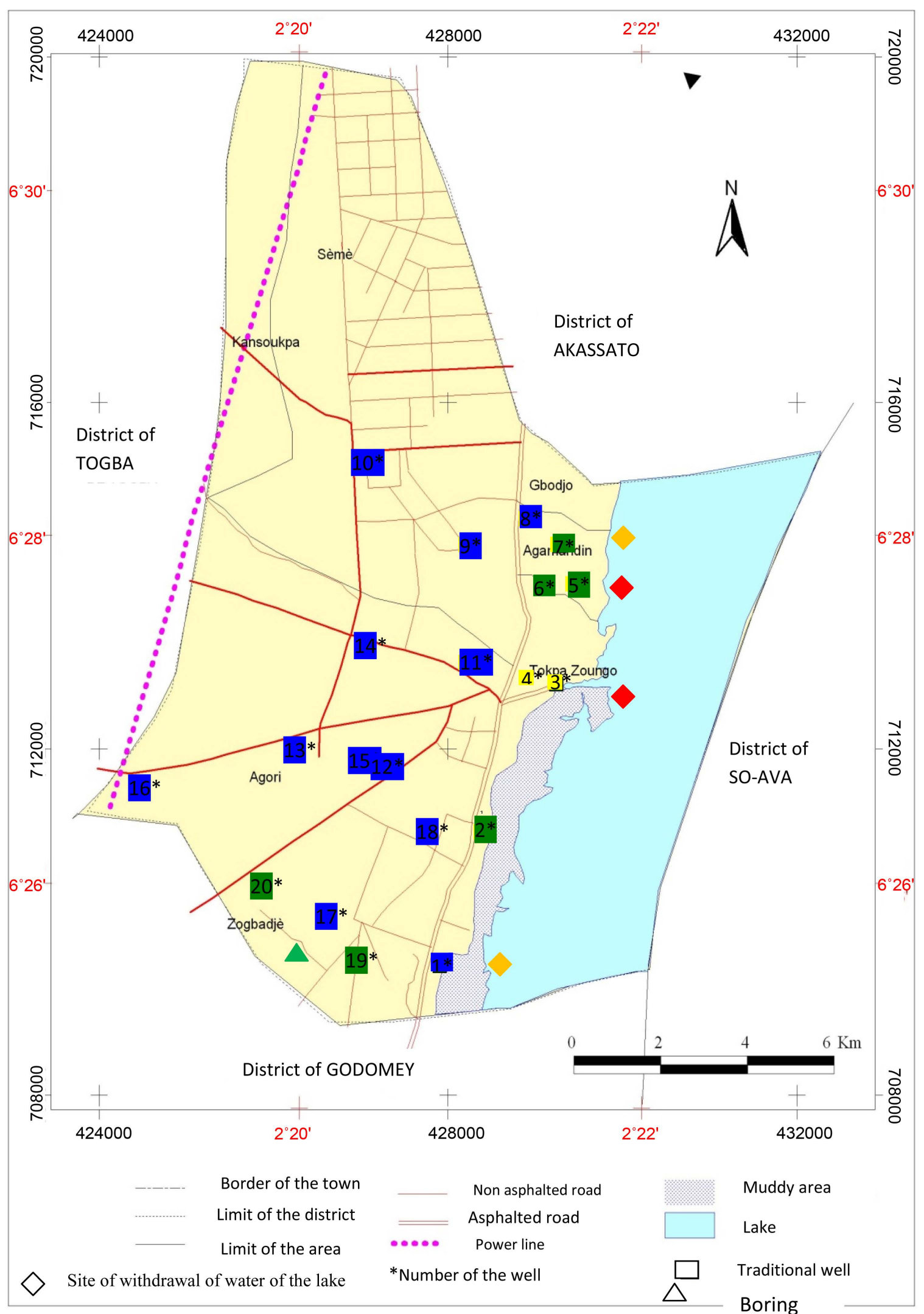

Figure 4. Card of distribution of indication of bacteriological contamination of the survey zone during the dry seasons. 


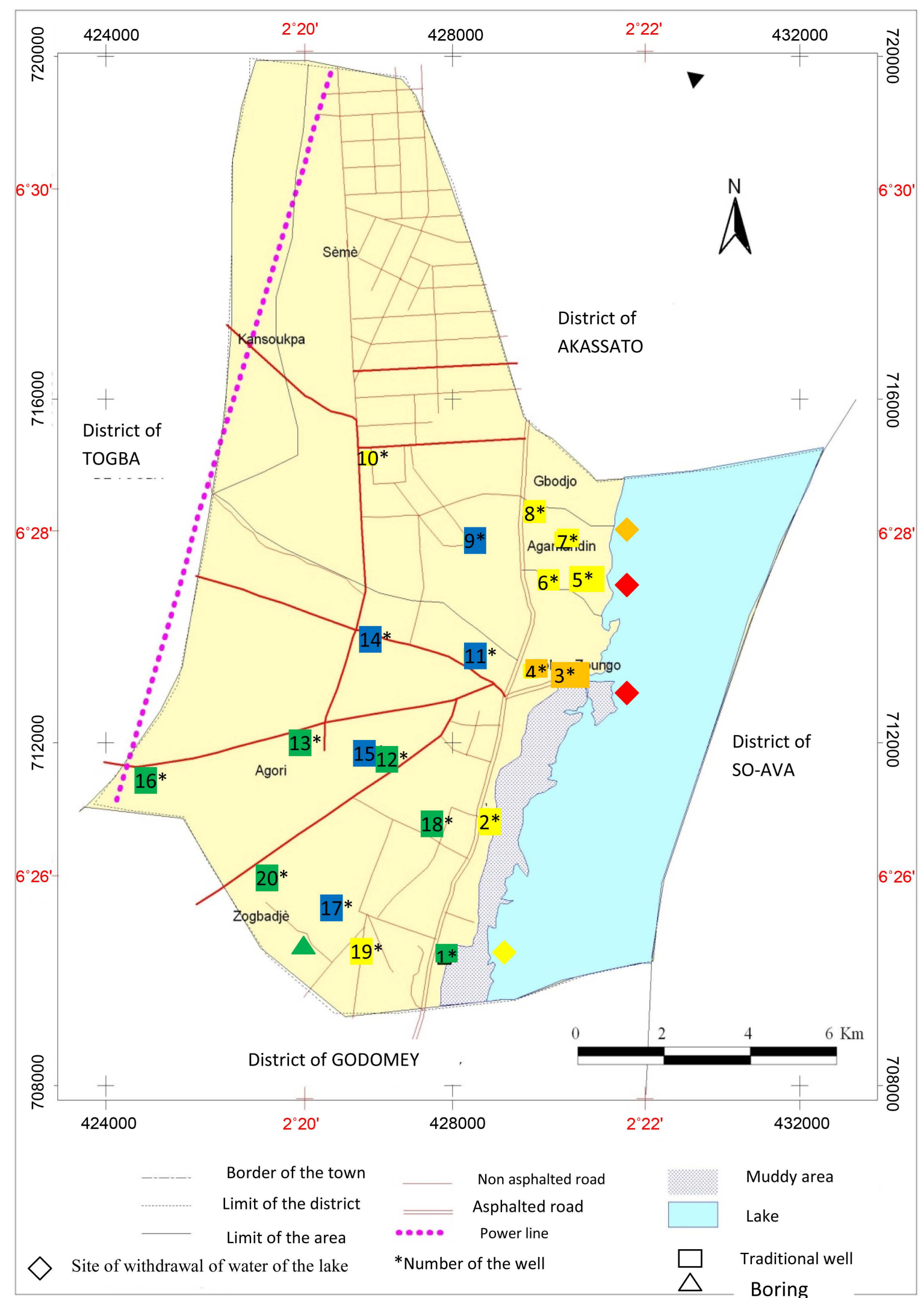

Figure 5. Card of distribution of indication of bacteriological contamination of the survey zone during the seasons of rains. 
Table 3. Seasonal variation of the microbiological quality Indications (IQM).

\begin{tabular}{|c|c|c|c|}
\hline \multirow{2}{*}{ Nature of water sample } & \multirow{2}{*}{ Points of withdrawals } & \multicolumn{2}{|c|}{ Microbiological quality indication (IQM) } \\
\hline & & Season dries & Season of rains \\
\hline Water of & $\mathrm{L}_{1}$ & 2.6 & 3 \\
\hline Surface & $\mathrm{L}_{2}$ & 1.3 & 1.6 \\
\hline Lake & $\mathrm{L}_{3}$ & 1.3 & 1.6 \\
\hline \multirow[t]{3}{*}{ Nokoué } & $\mathrm{L}_{4}$ & 2 & 2.3 \\
\hline & $\mathrm{P}_{1}$ & 4.3 & 3.6 \\
\hline & $\mathrm{P}_{2}$ & 3.6 & 3 \\
\hline \multirow[t]{4}{*}{ Water } & $\mathrm{P}_{3}$ & 3 & 2.3 \\
\hline & $\mathrm{P}_{4}$ & 3 & 2.3 \\
\hline & $\mathrm{P}_{5}$ & 3.6 & 3 \\
\hline & $\mathrm{P}_{6}$ & 4 & 3.3 \\
\hline \multirow[t]{5}{*}{ of } & $\mathrm{P}_{7}$ & 3.6 & 3 \\
\hline & $\mathrm{P}_{8}$ & 4.3 & 3.6 \\
\hline & $\mathrm{P}_{9}$ & 5 & 4.6 \\
\hline & $\mathrm{P}_{10}$ & 5 & 5 \\
\hline & $\mathrm{P}_{11}$ & 5 & 4.3 \\
\hline \multirow[t]{6}{*}{ Traditional } & $\mathrm{P}_{12}$ & 4.3 & 3.6 \\
\hline & $\mathrm{P}_{13}$ & 4.3 & 3.6 \\
\hline & $\mathrm{P}_{14}$ & 5 & 4.6 \\
\hline & $\mathrm{P}_{15}$ & 5 & 4.3 \\
\hline & $\mathrm{P}_{16}$ & 4.6 & 4 \\
\hline & $\mathrm{P}_{17}$ & 5 & 5 \\
\hline \multirow[t]{3}{*}{ Well } & $\mathrm{P}_{18}$ & 4.3 & 3.6 \\
\hline & $\mathrm{P}_{19}$ & 4 & 3 \\
\hline & $\mathrm{P}_{20}$ & 4.3 & 3.6 \\
\hline Water of deep boring & $\mathrm{F}$ & 4 & 3.6 \\
\hline
\end{tabular}

infiltrations encourage the underground water pollution by the septic pits and the latrines that are not insulated in the region of survey. However, the population of the survey region essentially consumes the underground waters. It justifies the fact that, during the seasons of rain, in the region of survey, several people developed waterborne diseases and the cholera provoked some deaths.

\section{References}

[1] Evette, A., Peyras, L., François, H. and Gaucherand, S. (2011) Environmental Risks and Impacts of Mountain Reservoirs for Artificial Snow Production in a Context of Climate Change. Journal of Alpine Research, 99-4. http://dx.doi.org/10.4000/rga.1481

[2] Cabral, J. (2010) Water Microbiology. Bacterial Pathogens and Water. International Journal of Environmental Research and Public Health, 7, 3657-3703. http://dx.doi.org/10.3390/ijerph7103657

[3] Dovonou, F. (2012) Diagnostic qualitatif et environnemental de l'aquifère superficiel du champ de captage intensif de Godomey au Bénin (Afrique de l’Ouest): Eléments pour un plan d'actions stratégiques de protection des ressources en eau souterraine exploitées. Thèse de doctorat, spécialité hydrologie, CIPMA, FAST, UAC.

[4] Hounsinou, P. (2012) Pollution chimique et bactérienne des eaux de pluie, des eaux de surface et des eaux souterraines 
dans la commune d’Abomey-Calavi (Sud Bénin). Mémoire pour l’obtention du Diplôme d’Etudes Approfondies en Chimie et Applications option chimie minérale, Faculté des Sciences et Techniques, Université d'Abomey-Calavi (UAC).

[5] Degbé, C. (2004) La qualité de l'eau de puits dans la commune d’Abomey-Calavi et les facteurs exogènes de sa pollution. Mémoire pour l'obtention du Diplôme d'Etudes Approfondies en gestion de l'environnement; spécialité environnement et santé. Université d'Abomey-Calavi (UAC).

[6] Hounsinou, P., Mama, D., Alassane, A. and Boukari, A. (2014) Hydrogeology and Chemistry Synthesis of the deep Boring of the Township of Abomey-Calavi, Benin. Research Journal of Chemical Sciences, 4, 103-116.

[7] Hounsinou, P., Mama, D., Dovonou, F., Dedjiho, A. and Sohounhloue, A. (2015) Organic Pollution Indication as Tracer for the Pollution of Well Water: The Example of the District of Abomey-Calavi (Benin). Research Journal of Chemical Sciences, 5, 49-54.

[8] Kherifi, W. and Kherici-Bousnoubra, H. (2012) Evolution saisonnière de la qualite microbiologique des eaux du lac Mellah (nord-est algerien). Larhyss Journal, no. 11, 109-111. 